\title{
STRATEGI KOMUNIKASI PEMASARAN SEPTIA HOTEL YOGYAKARTA
}

\author{
Oleh: Ardiyanto Wardhana \\ Dosen Ilmu Komunikasi UAD Yogyakarta
}

\begin{abstract}
Intisari
Maraknya pembangunan hotel disetiap sudut kota Yogyakarta mengindikasikan bahwa usaha bidang jasa khususnya perhotelan memiliki daya tarik bagi investor. Tentu saja hal tersebut akan menciptakan lapangan kerja baru serta meningkatknya pendapatan asli daerah. Banyaknya hotelhotel baru di Yogyakarta maka secara otomatis akan menimbulkan dampak ketatnya persaingan bisnis di antara hotel tersebut. Industri perhotelan dituntut untuk memberikan dan selalu mengembangkan layanan prima dan memiliki fasilitas yang memadai. Tentunya diperlukan upaya-upaya ataupun strategi untuk mengatasi permasalahan tersebut.
\end{abstract}

Kata kunci: Komunikasi Pemasaran, Differensiasi, Industri Perhotelan

\begin{abstract}
The rise of the construction of hotels in every corner of the city of Yogyakarta indicate that the business service sector, especially the hospitality has appeal for investors. Of course it will create new jobs as well as the rise in revenue. The number of new hotels in Yogyakarta, it will automatically have an impact on the business competition between the hotel. The hospitality industry is required to provide and constantly develop excellent services and have adequate facilities. Surely required efforts or strategies to overcome these problems.
\end{abstract}

Keywords: Marketing Communications, Differentiation, Hospitality Industry

\section{A. PENDAhULUAN}

Pertumbuhan hotel di Yogyakarta yang semakin meningkat menandakan para investor tertarik menanamkan dananya dalam bentuk usaha jasa perhotelan. Hal ini terlihat hampir di setiap sudut kota Yogyakarta banyak hotel mulai dilakukan pembangunan mulai yang berada di pinggir jalan utama kota Yogyakarta hingga di pinggiran bahkan di ganggang perumahan penduduk. Penanaman investasi tersebut layak di sambut baik karena tentu saja akan berdampak positif bagi masyarakat, mulai dari terserapnya banyak tenaga kerja hingga memperoleh pendapatan asli daerah. Terdorongnya usaha perhotelan tentu saja memiliki dampak positif bagi sektor-sektor lainnya seperti transportasi, kuliner, kerajinan dan obyek wisata.

Pariwisata dan perhotelan merupakan dua hal yang saling terkait. Tumbuhnya tren pembangunan perhotelan di Yogyakarta tentu saja tak lepas dari industri pariwisata yang ada. Menurut Badan Pusat Statistik (BPS) di tahun 2013 yang lalu jumlah wisatawan mancanegara sebanyak 8,8 juta telah datang ke Indonesia. Tingginya kunjungan wisatawan ke 
Indonesia menjadikan Indonesia berada di peringkat ketiga se-Asia dalam bidang pembangunan dan investasi perhotelan. Pertumbuhan yang besar tersebut pasti membawa dampak positif bagi hotel yang tumbuh dan akan menyerap lebih banyak tenaga kerja di sektor bisnis perhotelan.

Melonjaknya pariwisata di berbagai wilayah di Asia termasuk Indonesia dipercaya dapat mendorong pertumbuhan ekonomi yang positif bagi industri perhotelan. Badan Pusat Statistik menjelaskan bahwa jumlah hotel di DIY hingga awal tahun 2013 sebanyak 401 unit meliputi 39 hotel berbintang dan 362 hotel non bintang.

Sebagai sebuah industri yang bergerak di bidang jasa perhotelan, hotel memiliki beberapa jenis hotel yang pengelolaannya dilakukan secara komersial sesuai dengan tujuan pelayanan yang ditawarkan kepada publiknya (Alma, 2002).

1. Residensial Hotel, yaitu hotel yang menerima tamu untuk menginap dalam jangka waktu yang lama namun tidak untuk menetap.

2. Transit Hotel atau Commercial Hotel, yaitu hotel yang menyediakan kamar dan makan pagi bagi para tamu yang sedang melakukan perjalanan untuk keperluan bisnis dalam jangka waktu yang relatif pendek dan hotel seperti ini sering dijumpai di pusat kota atau terletak pada daerah-daerah yang ramai.

3. Resort Hotel, adalah hotel yang terletak di daerah-daerah peristirahatan atau liburan, dimana akomodasi yang disediakan hanya di saat-saat tertentu.

Tingginya pembangunan di bidang bisnis perhotelan belum tentu sinkron dengan jumlah tingkat hunian (okupansi) hotel di Indonesia. Di Yogyakarta persaingan industri perhotelan semakin ketat seiring munculnya hotel-hotel baru. Hotel non-bintang memiliki paling terdampak pada pembangunan hotel baru tersebut.

Berdasarkan data dari Badan Pusat Statistik (BPS) DIY jumlah wisatawan yang menginap di hotel selama bulan desember 2013 tercatat sebanyak 376.320 orang yang terdiri dari 362.711 orang wisatawan nusantara dan 13.609 wisatawan mancanegara. Dari jumlah tersebut yang menginap di hotel bintang sebanyak 134.669 orang dan 241.651 orang menginap di hotel non bintang/akomodasi lain (yogyakarta.bps.go.id)

Rendahnya okupansi hotel kelas melati salah satunya disebabkan banyaknya hotelhotel berbintang dengan menawarkan berbagai macam kelengkapan fasilitas yang lengkap serta harga yang bersaing. Akibatnya banyak wisatawan yang lebih menginap di hotel berbintang dikarenakan harganya yang hampir sama. Banyaknya hotel yang tingkat okupansinya rendah dikhawatirkan akan menyebabkan perang tarif sehingga menimbulkan iklim bisnis yang kurang sehat. Oleh karena itu perlu di lakukan langkah-langkah strategis agar tingkat hunian hotel kelas melati mengalami peningkatan dan dapat bertahan dari gempuran hotel-hotel baru berbintang.

\section{B. TINJAUAN PUSTAKA}

\section{Strategi Komunikasi}

Kata "strategi" berasal dari bahasa Yunani, yakni strategos yang diterjemahkan sebagai "komandan militer" di zaman demokrasi Athena. Menurut kotler (1997) strategi sebagai permainan utuk mencapai sasaran usaha dengan menggunakan pemikiran strategis. Konsep strategi banyak dipakai dalam berbagai bidang tidak terkecuali dalam dunia bisnis 
Diterbitkan oleh Program Studi Ilmu Komunikasi

Universitas Ahmad Dahlan Yogyakarta

misalnya Sun Tzu, (dalam The Art War), Hannibal dan Carl Clausewitz. Dalam implementtasi sebuah strategi pemasaran tidak lengkap bila tidak mengikutsertakan unsur komunikasi di dalamnya. Ini disebabkan sebaik apapun rencana strategi pemasaran tersebut maka program akan berjalan kurang efektif dan efisien. Strategi merupakan upaya-upaya yang dilakukan untuk mencapai tujuan jangka panjang. Pengertian strategi adalah rencana yang disatukan, luas dan berintegrasi yang menghubungkan keunggulan strategis perusahaan dengan tantangan lingkungan, yang dirancang untuk memastikan bahwa tujuan utama dari perusahaan dapat dicapai melalui pelaksanaan yang tepat oleh organisasi (Glueck dan Jauch, 1989).

Di setiap strategi bisnis diperlukan komunikasi yang baik antara komunikator dengan komunikan dalam hal ini penjual dan pembeli. Bila komunikasi yang dibangun telah terjalin dengan baik maka akan dengan mudah membujuk mereka apa yang mereka jual. Seringkali unsur komunikasi bagi pelaku pemasaran atau pebisnis diabaikan. Mereka menjual produk tanpa berkomunikasi baik secara langsung maupun tidak langsung dengan para konsumennya. Banyak sekali manfaat yang diambil apabila unsur komunikasi digunakan dalam proses strategi pemasaran.

\section{Komunikasi Pemasaran}

Salah satu kunci suksesnya kegiatan pemasaran adalah promosi. Secara umum promosi dilakukan melalui beberapa elemen. Adapun kegiatan komunikasi pemasaran mempunyai elemen-elemen (Belch and Belch, 2004: 16) yakni: Periklanan (advertising), merupakan awal dalam memasarkan sebuah produk, berfungsi untuk menginformasikan serta mempengaruhi konsumen agar bersedia menggunakan produk atau jasa yang ditawarkan. Sifatnya yang mampu menembus menjadikan iklan banyak digunakan untuk mempengaruhi konsumen yang besar. Bentuk iklan merupakan yang terdapat di media massa cetak maupun elektronik, seperti brosur, billboard, logo. Iklan juga dapat digunakan untuk membuat sebuah citra terhadap merek hal ini berpengaruh terhadap kredibilitas perusahaan sebagai produsen yang mengeluarkan produk. Selain itu melalui iklan dapat menjadikan produk yang ditawarkan berbeda dengan produk lainnya sehingga mempunyai daya jual yang tinggi. Pemasaran Langsung (Direct Marketing), merupakan kegiatan promosi yang ditujukan langsung kepada konsumen dengan harapan akan mendapat respon, seperti surat, $e$ mail, dan telepon. Pemasaran langsung meliputi berbagai aktivitas seperti manajemen database, penjualan langsung, telemarketing serta iklan respon langsung melalui direct mail seperti internet. Terjadinya perubahan gaya hidup dimana seseorang tidak perlu lagi berbelanja dengan mengunjungi toko tetapi dapat melalui telepon. Interaktif/pemasaran internet (interactive/internet marketing), yakni menggunakan internet untuk melakukan kegiatan pemasaran, khususnya melalui World Wide Web. Sifatnya yang menarik menjadikan internet sebagai media promosi efektif untuk berkomunikasi dengan konsumen. Promosi penjualan (sales promotion), merupakan aktivitas marketing yang memberikan nilai atau insentif ekstra untuk satuan penjualan, distributor atau konsumen akhir dan dapat menstimulasi penjualan langsung. Publisitas/hubungan masyarakat (publicity/public relations), Publisitas adalah bentuk penyajian dan penyebaran ide, barang dan jasa secara non personal. Sedangkan penjualan perorangan (personal selling), Merupakan komunikasi yang dilakukan secara langsung atau tatap muka antara penjual dan pembeli. Dari interaksi tersebut 
marketer dapat melihat komunikasi yang dilakukan bersifat fleksibel, dalam arti penjual diperbolehkan untuk menyesuaikan pesan dengan kebutuhan atau situasi konsumennya.

Didorong oleh kemajuan dalam bidang teknologi penggunaan media interaktif sebagai salah satu elemen pemasaran memiliki pengaruh yang sangat besar saat ini untuk berkomunikasi dengan target pasarnya. Melalui media interaktif seorang marketer dapat mengetahui respon pasar berkaitan dengan produk yang ditawarkannya.

\section{Hotel}

Terdapat perbedaan antara hotel dengan industri lainnya adalah: Industri hotel tergolong industri yang padat modal serta padat karya yang artinya dalam pengelolaannya memerlukan modal usaha yang besar dengan tenaga pekerja yang banyak pula. Dipengaruhi juga oleh keadaan dan perubahan yang terjadi pada sektor ekonomi, politik, sosial, budaya, dan keamanan dimana hotel tersebut berada. Menghasilkan dan memasarkan produknya bersamaan dengan tempat dimana jasa pelayanan dihasilkan. Memperlakukan pelanggan seperti raja selain juga memperlakukan pelanggan sebagai patner dalam usaha karena jasa pelayanan hotel sangat tergantung pada banyaknya pelanggan yang menggunakan fasilitas hotel tersebut.

\section{PEMBAHASAN}

\section{Industri Perhotelan}

Pariwisata saat ini merupakan suatu industri paling bertumbuh di dunia. Banyaknya destinasi wisata baru di sebuah daerah di tambah dengan kecanggihan teknologi yang ada pada saat ini menjadikan destinasi tersebut lebih dikenal dan menjadi daya tarik masyarakat untuk mengunjunginya. Kecanggihan teknologi saat ini memudahkan akses informasi ke penjuru dunia akan adanya suatu destinasi wisata. Pariwisata dan perhotelan merupakan simbiosis mutualisme, yakni saling menguntungkan.

Tumbuhnya industri perhotelan tidak lepas dari berkembangnya sektor pariwisata. Begitupun sebaliknya, pariwisata tidak akan bisa berkembang dengan baik tanpa didukung oleh industri perhotelan. Banyaknya hotel yang tumbuh subur menjadikan suatu daerah menjadi magnet tersendiri bagi masyarakat yang ingin berkunjung.

Termasuk di wilayah Daerah Istimewa Yogyakarta, pertumbuhan hotel akan semakin meningkat, ini dikarenakan faktor pertambahan jumlah kamar secara signifikan. Berdasarkan data yang di himpun dari BPS Provinsi DIY pada press release 1 Oktober 2014, Tingkat Penghunian Kamar (TPK) hotel di DIY secara rata-rata pada bulan Agustus 2014 sebesar 59.63 persen. Dari angka tersebut mengalami kenaikan sebesar 12,81 poin bila dibandingkan bulan Juli 2014 yang menunjuk besaran 46,82\%. Sedangkan untuk TPK hotel non bintang atau akomodasi lain sebesar 27,75 persen, juga mengalami kenaikan sebesar 7,99 poin dibandingkan bulan Juli 2014.

Dari data tersebut dapat disimpulkan adanya kenaikan di TPK masing-masing hotel baik kelas berbintang maupun non bintang. Banyak faktor yang bisa menimbulkan kenaikan tersebut. Diantaranya adalah, peningkatan ini dipicu oleh semakin banyaknya kunjungan mahasiswa yang melakukan study tour ataupun study banding ke Yogyakarta. Disam- 
Diterbitkan oleh Program Studi Ilmu Komunikasi

Universitas Ahmad Dahlan Yogyakarta

ping itu juga ada siswa yang baru lulus ujian sekolah menengah atas (SMA) dan datang berkunjung ke Yogyakarta bersama orang tuanya untuk mendaftarkan anak-anaknya melanjutkan studi ke perguruan tinggi di Yogyakarta. Tujuan kunjungan ke kota yang sarat predikat ini dikarenakan Yogyakarta juga disebut sebagai kota pelajar, sehingga dampak tidak hanya meningkatnya TPK Hotel tetapi dampak lain yang dirasakan terjadinya kemacetan lalu lintas di beberapa ruas jalan khususnya yang menjadi icon Kota Yogyakarta seperti Malioboro. Kondisi ini sudah berlangsung hampir tiap tahun ajaran baru dan di setiap hari libur nasional.

Namun juga apabila dilihat dari sisi yang berbeda, pembangunan hotel yang tidak bisa dikendalikan justru akan berdampak buruk terhadap karakteristik kota budaya, dan akan membuat Kota Yogyakarta akan semakin tidak nyaman. Ini dikarenakan tidak didukung dengan jalan yang memadai sehingga dapat ditemukan dimana-mana kemacetan khususnya di hari libur sekolah ataupun hari besar libur nasional, kurangnya transportasi juga drainase yang belum memadai. Bahkan dikhawatirkan apabila hal ini tidak ditanggulangi dengan baik bisa berakibat mengeringnya sumur para warga yang tinggal di sekitar hotel diakibatkan sumber air warga disedot untuk kepentingan perhotelan.

\section{Kondisi Pariwisata di Daerah Istimewa Yogyakarta (DIY)}

DIY memiliki luas daerah sekitar 3.185,80 km yang dibagi menjadi empat kabupaten dan satu kota yakni Kabupaten Sleman, Kabupaten Bantul, Kabupaten Gunung Kidul, Kabupaten Kulon Progo dan Kota Yogyakarta. DIY memiliki karakter wilayah yang beraneka ragam, secara fisiografis di sebelah utara dan barat laut merupakan daerah perbukitan dan pegunungan sedangkan di bagian utara terdapat gunung Merapi yang masih aktif hingga saat ini yang di kenal sebagai the most active volcano in the world. Gunung Merapi tersebut memiliki ciri erupsi khusus yaitu membentuk awan panas wedus gembel yang mana merupakan satu-satunya di dunia. Pada bagian barat laut terdapat pegunungan Menoreh yang memiliki potensi sangat tinggi sebagai objek serta daya tarik wisata alam

\section{Strategi Komunikasi Pemasaran Septia Hotel}

Awal berdirinya Septia Hotel untuk memperkenalkan kepada masyarakat akan kehadiran hotel melati di Yogyakarta, maka pihak manajemen melakukan penyebaran brosur ke tempat-tempat yang dianggap menjadi target utama kunjungan wisatawan. Misalnya di rumah makan, stasiun, terminal bis. Pihak manajemen memberikan atau meletakkan brosur ditempat tersebut dengan harapan apabila diantara mereka ada yang membutuhkan tempat untuk menginap, sekaligus juga sebagai brand awareness bagi masyarakat.

Tidak hanya brosur yang dibagikan melainkan juga contact person dari manajemen dalam hal ini manajer operasional, juga diiming-imingi insentif dalam bentuk uang apabila bersedia membawa tamu yang sedang mencari penginapan dan bersedia menginap di Septia Hotel.

Tidak hanya tukang becak yang mangkal di Stasiun Kereta Api, tapi juga seluruh tukang becak yang dapat ditemui di sepanjang Malioboro bahkan juga tukang ojek. Ini tentu saja memakan waktu dan cukup melelahkan, tetapi upaya tersebut cukup efektif dilakukan karena, umumnya, sangat jarang pemasaran dilakukan secara langsung terhadap "ujung tombak" dalam menarik para calon tamu hotel. Ada beberapa alasan yang dikemukakan 
pihak manajemen Septia Hotel, mengapa tukang becak menjadi sasaran pemasaran langsung (direct marketing). Ini dikarenakan, setiap tukang becak selalu membawa penumpang yang notabene tidak hanya warga Yogyakarta melainkan juga para wisatawan. Kerap kali wisatawan menjadikan tukang becak sebagai sasaran tempat mencari informasi tentang sesuatu hal termasuk informasi penginapan hotel. Masih banyaknya wisatawan yang menggunakan becak di saat baru tiba di stasiun ataupun berjalan-jalan dari satu tempat ke tempat lain diantaranya adalah becak merupakan moda transportasi yang dianggap masih tradesional disamping delman yang ramah lingkungan, kecuali becak bermotor yang menggunakan sepeda motor sebagai penggeraknya. Becak dengan roda tiga serta pengemudi di belakang saat ini masih mudah ditemui di Yogyakarta.

Tidak hanya dengan mendatangi tukang becak saja, tetapi juga pihak manajemen hotel juga mendatangi agen perjalanan wisata (travel). Agen perjalanan wisata seringkali telah memiliki kerjasama dengan lembaga-lembaga lain apabila melakukan kunjungan ke suatu daerah wisata. Momentum inilah yang dimanfaatkan manajemen sebagai upaya promosi dalam meningkatkan tingkat hunian kamar hotel. Untuk menjadikan pilihan utama tempat menginap bagi rombongan yang di bawa agen perjalanan wisata, maka para tour leader (TL) diberikan kamar yang sama dengan tamu-tamu yang menginap lainnya, lengkap dengan air conditioner (AC) dan lainnya sesuai standar. Hal ini menjadi celah penting bagi manajemen Septia Hotel karena TL dari agen perjalanan wisata menjadi penentu dalam memilih akomodasi penginapan.

Hal penentu tersebut akan dirasakan pihak manajemen di kemudian hari, di saat agen perjalanan wisata akan datang yang kedua kalinya dan menginap di Septia Hotel. Dapat diartikan TL memperoleh kepuasan dari rombongan yang dibawa sebelumnya sehingga berimbas terhadap kunjungan kedua.

Aktivitas marketing yang satu ini memberikan nilai atau insentif ekstra untuk satuan penjualan, distributor atau konsumen akhir dan dapat menstimulasi penjualan langsung. Ini diberlakukan di Septia Hotel hingga saat ini, dengan diiming-imingi insentif dalam bentuk uang apabila bersedia membawa tamu yang sedang mencari penginapan dan bersedia menginap di Septia Hotel. Ini berlaku bagi para tukang becak sebagai garda terdepan dalam menarik pelanggan tamu hotel. Upaya promosi penjualan seperti ini tidak hanya berlaku di Septia Hotel, melainkan juga hampir di seluruh mayoritas hotel yang ada di Yogyakarta. Yang membedakan adalah kecepatan dan jumlah nominal yang berikan. Maksudnya adalah jumlah yang diberikan lebih besar dari hotel-hotel yang lain serta bisa langsung dibayarkan di saat tamu tersebut telah menandatangani atau bersedia cek in di hotel tersebut

\section{SIMPULAN}

Berpredikat sebagai kota pariwisata, Daerah Istimewa yogyakarta (DIY) tumbuh sebagai kota yang banyak dikunjungi wisatawan. Salah satu yang menjadi indikator adalah pertumbuhan hotel-hotel baru yang cukup signifikan. Terlihat hampir di setiap sudut kota Yogyakarta banyak hotel mulai dilakukan pembangunan mulai yang berada di pinggir jalan utama kota Yogyakarta hingga di pinggiran bahkan di gang-gang perumahan penduduk. Penanaman investasi tersebut layak di sambut baik karena tentu saja akan berdampak posi- 
Diterbitkan oleh Program Studi Ilmu Komunikasi

Universitas Ahmad Dahlan Yogyakarta

tif bagi masyarakat, mulai dari terserapnya banyak tenaga kerja hingga memperoleh pendapatan asli daerah.

Septia Hotel merupakan sebuah hotel yang dirancang khusus untuk para wisatawan yang menginginkan sebuah penginapan murah, dengan kamar yang mampu menampung banyak orang, berada di tengah kota, tidak jauh dari stasiun kereta api, serta dekat dengan icon wisata belanja di yogyakarta yakni malioboro. Berada di kawasan strategis menjadikan hotel tersebut menjadi pilihan utama untuk dikunjungi.

Dalam mengkomunikasikan suatu produk kepada pelanggan, maka promosi merupakan salah satu upaya yang dapat dilakukan. Dalam industri perhotelan dalam hal ini Septia Hotel telah menerapkan elemen-elemen komunikasi pemasaran, seperti periklanan, pemasaran langsung, Interaktif/pemasaran internet, Promosi penjualan, Publisitas/hubungan masyarakat dan Penjualan peroranganDalam industri perhotelan dalam hal ini Septia Hotel telah menerapkan elemen-elemen komunikasi pemasaran, seperti periklanan, pemasaran langsung, Interaktif/pemasaran internet, Promosi penjualan, Publisitas/hubungan masyarakat dan Penjualan perorangan.

Dengan usia hotel yang masih tergolong muda, maka diperlukan pemahaman (awareness) ke seluruh lapisan. Salah satu upaya yang dilakukan adalah dengan mendatangi para tukang becak dan tukang ojek yang ada di Stasiun Tugu Yogyakarta. Tidak hanya brosur yang dibagikan melainkan juga contact person dari manajemen dalam hal ini manajer operasional, juga diiming-imingi insentif dalam bentuk uang apabila bersedia membawa tamu yang sedang mencari penginapan dan bersedia menginap di Septia Hotel. Beberapa alasan yang dikemukakan pihak manajemen Septia Hotel, mengapa tukang becak menjadi sasaran pemasaran langsung (direct marketing). Hal ini dikarenakan, setiap tukang becak selalu membawa penumpang yang notabene tidak hanya warga Yogyakarta melainkan juga para wisatawan. Kerap kali wisatawan menjadikan tukang becak sebagai sasaran tempat mencari informasi tentang sesuatu hal termasuk informasi penginapan hotel. Masih banyaknya wisatawan yang menggunakan becak di saat baru tiba di stasiun ataupun berjalan-jalan dari satu tempat ke tempat lain diantaranya adalah becak merupakan moda transportasi yang dianggap masih tradisional disamping delman yang ramah lingkungan, kecuali becak bermotor yang menggunakan sepeda motor sebagai penggeraknya. Becak dengan roda tiga serta pengemudi di belakang saat ini masih mudah ditemui di Yogyakarta.

Menjalin kerjasama dengan Agen Perjalanan Wisata (APW) merupakan salah satu kesuksesan dalam mengisi tingkat hunian kamar hotel, seringkali telah memiliki kerjasama dengan lembaga-lembaga lain apabila melakukan kunjungan ke suatu daerah wisata. Momentum inilah yang dimanfaatkan manajemen sebagai upaya promosi dalam meningkatkan tingkat hunian kamar hotel. Untuk menjadikan pilihan utama tempat menginap bagi rombongan yang di bawa agen perjalanan wisata, maka para tour leader (TL) diberikan kamar yang sama dengan tamu-tamu yang menginap lainnya, lengkap dengan air conditioner (AC) dan lainnya sesuai standar. Hal ini menjadi celah penting bagi manajemen Septia Hotel karena TL dari agen perjalanan wisata menjadi penentu dalam memilih akomodasi penginapan.

Konsep komunikasi pemasaran yang dikemukakan oleh Shimp meliputi beberapa tahapan. Tahap pertama adalah dengan menyusun struktur organisasi pengambilan keputusan dalam komunikasi pemasaran. Tahap yang kedua adalah melakukan monitoring dan 
mengelola lingkungan pemasaran. Tahap yang ketiga meliputi pilihan umum, pilihan spesifik dan evaluasi program. Untuk pilihan umum terdiri dari penentuan sasaran/target, menetapkan tujuan dan menyusun anggaran. Sedangkan pilihan spesifik terdiri dari memadukan berbagai elemen, menciptakan pesan, pemilihan media dan menetapkan momentum. Evaluasi program dilakukan untuk mengukur hasil yang telah dicapai. Tahap yang ke empat merupakan inti dari aktivitas komunikasi pemasaran yakni meningkatkan ekuitas merek.

Konsep tersebut tepat apabila dipergunakan pada industri perhotelan sangatlah tepat. Dalam hal ini Septia Hotel. Konsep tersebut menjelaskan tahap demi tahap proses yang harus dilalui, dan di setiap tahapannya mempunyai keterkaitan antara satu dengan yang lainnya. Septia hotel yang bergerak di industri perhotelan di dalam menjawab tantangan ke depan terkait hunian hotel perlu menerapkan strategi khusus. Seiring banyaknya hotel-hotel baru di Yogyakarta maka secara otomatis akan menimbulkan dampak ketatnya persaingan bisnis di antara hotel tersebut. Industri perhotelan dituntut untuk memberikan dan selalu mengembangkan layanan prima dan memiliki fasilitas yang memadai. Melonjaknya pariwisata di berbagai wilayah di Asia termasuk Indonesia dipercaya dapat mendorong pertumbuhan ekonomi yang positif bagi industri perhotelan. Badan Pusat Statistik menjelaskan bahwa jumlah hotel di DIY hingga awal tahun 2013 sebanyak 401 unit meliputi 39 hotel berbintang dan 362 hotel non bintang.

Saat ini hotel yang kerap kali dikunjungi atau dijadikan tempat menginap bagi wisatawan adalah yang berada di kawasan pusat wisata seperti malioboro atau kawasan perbelanjaan. Lokasi tersebut akan menguntungkan pihak hotel sehingga tidak terlalu susah untuk menarik minat tamu hotel meski harus bersaing dengan hotel-hotel lain yang juga telah hadir ditengah-tengah pusat perbelanjaan malioboro 
Diterbitkan oleh Program Studi IImu Komunikasi

Universitas Ahmad Dahlan Yogyakarta

\section{DAFTAR PUSTAKA}

\section{BUKU}

Batra, Rajeev. John G. Myers., David A. Aaker. 1995. Advertising Management. Prentice Hall, $5^{\text {th }} \mathrm{Ed}$.

Belch, George E., and Michael A. Belch. 2004. Advertising and Promotion: An Integrated Marketing Communications Perspective. Mc. Graw-Hill, $6^{\text {th }}$ ed.

Bogdan, Robert. and Steven J. Taylor. 1975. Introduction to Qualitative Research Methods: A Phenomenological Approach to The Social Sciences. John Wiley and Sons.

Kartajaya, Hermawan dan Yuswohady. 2005. Attracting Tourists, Traders, Investors: Strategi Memasarkan Daerah di Era Otonomi. Jakarta: MarkPlus\&Co.

Kasali, Rhenald. 2003. Membidik Pasar Indonesia: Segmentasi, Targeting dan Positioning. Jakarta: Gramedia Pustaka Utama. Cet. 6.

Kotler, Philip dan Gary Armstrong. 2001. Prinsip-Prinsip Pemasaran (alih bahasa, Damos Sihombing). Jakarta: Erlangga, Ed. 8.

Kotler, Philip. John Bowen, James Makens. 2002. Pemasaran Perhotelan dan Kepariwisataan (alih bahasa: Alexander Sindoro). Jakarta: Prehallindo, Jilid 1.

Miles, Matthew B. dan A. Michael Huberman. 1992. Analisis Data Kualitatif: Buku Sumber Tentang Metode-Metode Baru (Penerjemah: Tjetjep Rohendi Rohidi). Jakarta: Penerbit Universitas Indonesia (UI-Press). Cet. 1.

Moleong, Lexy J. 2005. Metodologi Penelitian Kualitatif. Bandung: PT Remaja Rosdakarya. Cet. 21.

Muhajir, Noeng. 1989. Metode Penelitian Kualitatif. Yogyakarta: Rake Sarasin.

\section{WEBSITE}

http://jogjanews.com/sudah-berizin-pembangunan-20-hotel-baru-di-kota-jogja2014-2015

http://puspar.ugm.ac.id/webpuspar/?p=1122 
... hal tersebut sejalan dengan temuan (Krug, 2006) bahwa sebagian kecil pengguna Web yang membaca halaman-halaman Web, melainkan scanning - membaca cepat dengan melihat kata-kata atau frase yang mencolok.

Penulisan daftar acuan menggunakan sistem Harvard. Semua yang tertera dalam daftar acuan harus dirujuk di dalam naskah. Daftar referensi ditulis urut abjad secara ascending. Contoh penulisan daftar acuan dapat dilihat di bagian Referensi.

8. Daftar pustaka disajikan secara alfabetik dan kronologis mengikuti tatacara seperti contoh dibawah ini.

Contoh:

Bohrer, S., Zielke, T., \& Freiburg, V. (1995), "Integrated obstacle detection framework for intelligent cruise control on motorways", makalah presentasi pada IEEE Intelligent Vehicles Symposium. Detroit, MI: Piscataway.

Brookshear, J. G. (2003), Computer science: Suatu pengantar (edisi 7), Terj. Computer science: An overview ( $7^{\text {th }}$ ed.), I. Hardiansyah (Pen.), H. W. Hardiani (Ed.). Jakarta: Erlangga. 